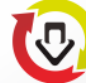

Check for

updates

\title{
Determinants of Accounting Students Understanding of Riba
}

\author{
Sigit Arie Wibowo* and Dea Rizaldi Mulantono
}

\section{OP OPE}

Department of Accounting, Universitas Muhammadiyah Yogyakarta, JL. Brawijaya, Tamantirto, Kasihan, Bantul, Yogyakarta Special Region, Indonesia

*Correspondence: sigit_arwi@yahoo.co.id This article is avalilable in: http://journal.umy.ac.id/index.php/ai DOI: 10.18196/jai.1902103

\section{Citation:}

Wibowo, S. A., \& Mulantono, D. R. (2018). Determinants of Accounting Students Understanding of Riba. Journal of Accounting and Investment, 19(2), 226-238.

\section{Received:}

16 April 2018

\section{Reviewed:}

15 April 2018

Revised:

15 May 2018

\section{Accepted:}

31 July 2018

\section{Copyright: (C) 2018}

Wibowo and Mulantono.

This is an open access article distributed under the terms of the Creative Commons Attribution

License, which permits unrestricted use, distribution, and reproduction in any medium, provided the original author and source are credited.
ABSTRACT: Currently, riba is one of the hot issues that often discussed in the field of sharia accounting and accounting student education in Islamic universities, which is sharia accounting as the major concentration. This study aims empirically to examine and prove the influence of intrinsic education, extrinsic education, educational learning, family religiosity, friendship religiosity, and organizational religiosity on students Understanding of Riba. This study used the sample of Accounting students of the Muhammadiyah University of Yogyakarta. This research also used convenience sampling technique. From the 109 questionnaires, there were 100 questionnaires available for the further process. The data obtained was then processed by using multiple linear regression analysis. The results of this study indicate that all independent variables proposed in this study have a significant positive effect on the understanding of accounting students in riba.

KEYWORDS: Intrinsic education; Extrinsic education; Educational Learning; Religiosity [Family, Friendship, Organizational]; Student Understanding of Riba

\section{Introduction}

Riba has become one of the aspects that received the attention of many academics in the study of sharia accounting, especially in Indonesia (Rahmanti, 2012). It is affected by the increasing number of sharia accounting studies as an integral part of the development of Islamic economics nowadays. Practically, the economic system in Indonesia tends to use the capitalist financial system, which uses riba as one of the economic instruments.

The unavoidable reality today is the majority of the life of Islamic society in Indonesia is very close to the system that is identical with riba, for example, bank interest and leasing. From its history, riba developed from time to time and transformed in a vague form. The development has been happening since from the days of ignorance (jahiliyyah) until now. The apprehensive fact about riba is that this practice often considered normal and cannot be separated from various transactions. The assumption that riba is reasonable may not be far from the awareness of riba which initially is closely related to the understanding of riba itself.

The fact that almost all schools in Indonesia from a basic level to senior high school have not done adequate socialization related to riba. There is not even a subject that accommodates it. It makes the Muslim community's very weak in understanding riba. In reality, referring to Al-Qur'an Surah Ali Imron (30) verse $130^{1}$ and the hadith narrated by Imam Ahmad ${ }^{2}$ and

\footnotetext{
1 "O you who believe! Eat not Riba (usury) doubled and multiplied, but fear Allah that you may be successful." (Qs. Ali Imron [3]: 130)
} 
strengthened by the agreement of ulema through Decree of Indonesian Ulema Council Fatwa Number 1 of 2004 on Bank Interest (conventional) concluded that riba is a disobedience because it contains elements of injustice and harm others.

Based on the phenomenon above, the study related to the understanding of riba in the society is necessary to do, especially for accounting students as the determinant of understanding riba. Moreover, this riba-related study is still pretty rarely found in sharia accounting literature. Accounting students of Muhammadiyah University of Yogyakarta which one of the concentration is sharia accounting to be an intriguing object studied about the phenomenon of understanding about riba. Since accounting students are prospective individuals who will immediately fight in the field of business in the future, they will somewhat intersect with the practice of riba.

So far research related to student understanding about riba was done Rahmanti (2017). The study used a qualitative post-phenomenological approach in exploring the perceptions of accounting students related to riba. In contrast to Rahmanti (2017), this study used a questionnaire survey approach by examining several determinant variables derived from earlier studies: intrinsic education (Ma'rifah, 2013; Widyarini, 2017), extrinsic education (Rusmayani, 2017), learning education (Pawitasari, Mujahidin \& Fattah, 2015), family religiosity (Puspitawati, 2010), friendship religiosity (Fathurrohman, 2017), and organizational religiosity (Sulistyo, 2011).

This research is expected to provide theoretical contribution related to the development of the theory of education in accounting, especially on the issue of sharia accounting. Practically, the results of this study can provide useful information for the policy makers of Islamic education accounting curriculum in many Islamic universities in Indonesia, especially relevant to the determinants in improving students' understanding of riba.

\section{Literature Review and Hypothesis Development}

\section{Theory of Planned Behavior}

In their widely known Theory of Planned Behavior, Fishbein and Ajzen (1974) explain that any behavior can be predicted and occurred because of a plan. According to Fishbein and Ajzen (1975), there are three factors become determinant for a person in behaving, namely: attitude, subjective norm, perceived behavioral control. In the argument described in Ajzen and Fishbein's planned behavior theory $(1991,2005)$, it explains that intention is the aspect that becomes the antecedent of a person is behaving. It is in line with the stages of the ethical decision-making process (Jones, 1991; Cohen and Bennie, 2006) as presented in Figure 1.

\footnotetext{
2 "One dirham of riba money eaten by a person in the state of knowing that it is a riba money is greater than adultery as much as 36 times." HR. Ahmad from Abdulloh bin Hanzholah and judged sahih by Al Albani in Shahih al Jami', no. 3375)"[Nida-set Rahman li Expert of Faith $p$ 41]
} 


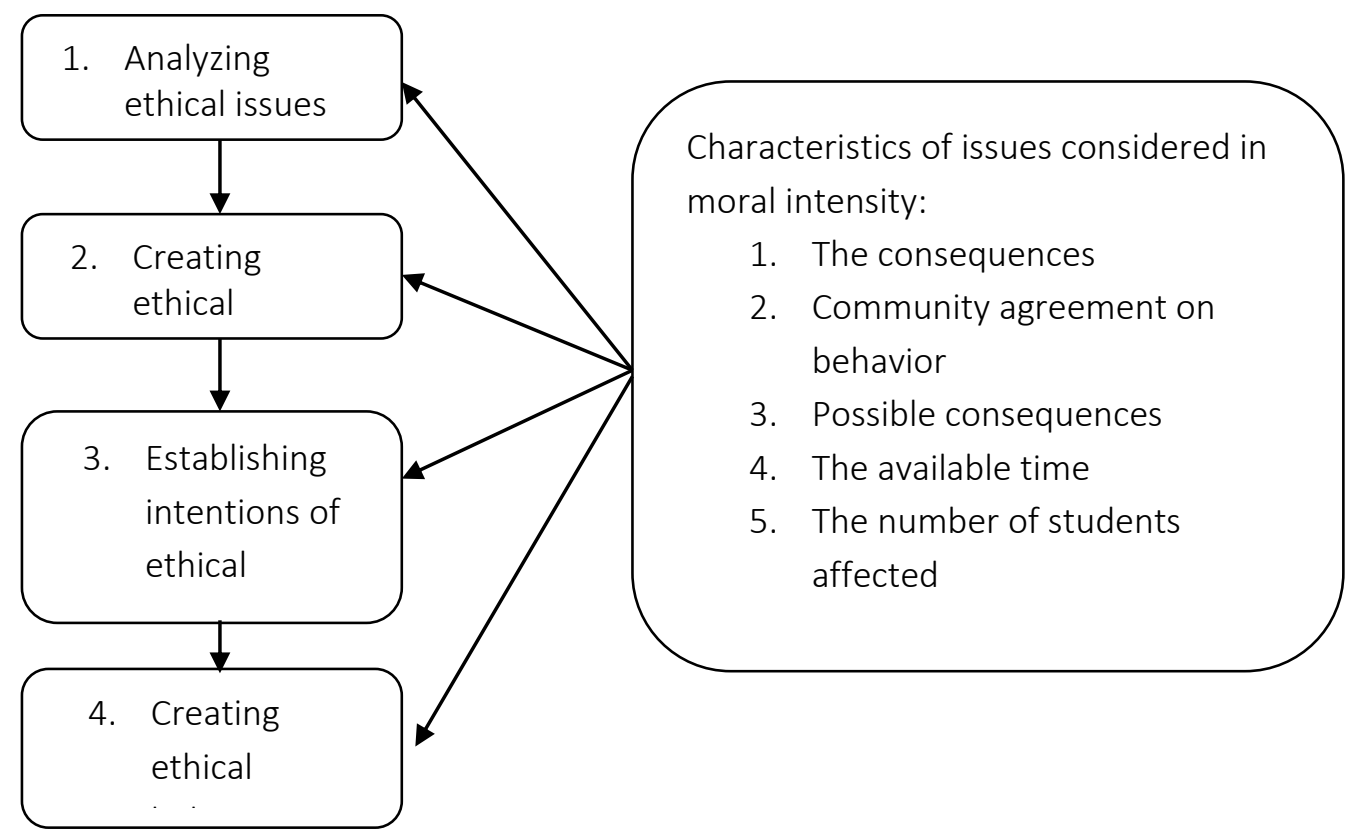

Figure 1. Ethical Decision-Making Process Source: Jones (1991) and Cohen and Bennie (2006)

Figure 1 shows that the attitude in behaving controls the intention to behave. The manner in behaving is a function of behavioral beliefs that are influenced by a religious believed by a person. Therefore, an understanding of matters relating to religious values; in the context of this research is riba, is a factor that can lead individuals to take attitude and behave (Rahma, Yulianti \& Sofyani, 2018).

\section{Riba}

According to the science of Arabic language, riba or usury has meaning as additional, grow and become high. Riba also has two meanings based on its term, among others is riba in the broad sense and riba in a narrow sense. Firstly, riba in the broad sense has the meaning of all transactions in the sale and purchase prohibited for Sharia or all forbidden transactions for Islam. Secondly, the meaning of riba in the narrow sense is a unique addition to one of two people who make transactions without any rewards otherwise (Ulum, 2016). Referring to the definition stipulated in the Decree of Indonesian Ulama Council Fatwa No. 1 of 2004; this definition is relevant to the idea of classical Islamic scholars, riba is defined as "additional (ziyadah) without any reward incurred due to suspension in payment in the previous agreement. It is known as Riba Nasi'ah. In the decree is explained that anything which includes riba one of which is the interest of conventional banks.

\section{Education and Riba}

Nowadays, Islamic economic education in Indonesia is increasing rapidly. We can see that from the rising number of universities in Indonesia that open courses related to Islamic economics, such as sharia/Islamic economics, sharia accounting, sharia management, Muamalah, Economics and Islamic Banking, and other similar programs. In the curriculum, the program 
combines the elements of science and religiosity. It is because the science of sharia cannot be apart from its basic foundation, namely the values of divinity and religious teachings (Rahma, Yulianti \& Sofyani, 2018; Yaya, 2005). In line with the arguments described by Fishbein and Ajzen (1974), individual learning of religious values will encourage individual to have stronger religiosity (see also: Sofyani \& Pramita, 2013).

In the context of learning associated to riba, students who take sharia accounting education which there is a discussion related to riba will have a correct understanding of riba (Sofyani, Anggraini \& Ayunani, 2017). Education itself in this study has two contexts, namely intrinsic and extrinsic (Ryan \& Deci, 2000). Mubarak (2016) argues that intrinsic education is a component of education that encourage the willingness to learn. It comes from within the individual concerned. Extrinsic education is anything that affects learning activities. It comes from outside and not absolute. Some previous studies support the concept of argument that education, both intrinsic (Ma'rifah, 2013; Widyarini, 2017) and extrinsic (Widyarini, 2017) will affect one's understanding of something; in this case is about riba. From the explanation, the first hypothesis in this study is as follows:

$H_{1 a}$ : Intrinsic factors of education have a positive effect on the understanding of riba.

$H_{1 b}$ : Extrinsic factors of education have a positive effect on the understanding of riba.

According to Juanda and Sofyani (2016), the concept of education associated with religious aspects, such as Islam, has a positive influence on the accounting students behavior especially anticipating dangerous acts; whether it is self-defeating or harmful to others, such as riba. Muhammad (2013) says that educational learning has a positive effect on individual attitudes and behavior. Someone who has an established education tends to also have a good understanding of behavior (Pawitasari, Mujahidin \& Fattah, 2017). The findings are compatible with Mayhew and Murphy's (2008) explanation. They state that education is an important point to educate accountants to be ethical especially when they are within the scope of their work. So it does happen in the religious education that is relevant to moral and ethical values. It influences one's ethical attitude, including a correct understanding of something that has an element of the ethical dilemma. From the above description, the third hypothesis of this study is as follows:

$\mathrm{H}_{2}$ : Educational Learning Factors have a positive effect on the understanding of riba

\section{Family, Friendship, Organizational Religiosity and Riba}

Maulana Maududi explains in his book about Riba, as quoted by Antonio (2011), that riba is a source of evil that can destroy the morale that has been formed by family and community relations. Riba will have an impact on the moral that has been created by family and society (Prasetya, 2015). Princess (2013) and Puspitawati (2010) present family religiosity influences one's understanding and attitude. 
A family is an informal organization that has the power to influence the pattern of views, attitudes, and behavior of its members. This argument is in line with the thought from Mazereeuw der Duijn Schouten, Graafland \& Kaptein (2014) which state that the religious values of individuals derived from character education in the family environment have a connection to the understanding and manner of the individual's behavior. Based on the results of the research, the fourth hypothesis in this study is:

$H_{3}$ : Family Religiosity Factors have a positive effect on the understanding of Riba.

In addition to one's family cannot be separated from social interaction with peers. Relationships affect the lives of both the words and actions of a person (Rahma, Yulianti \& Sofyani, 2018). Hanging out with friends who have bad behaviors will trigger unconscious imitation by other individuals, and ultimately lead to bad behavior also to the individuals involved in the friendship (Rahman, 2009). Conversely, when hanging out with friends who have good morals will have a positive impact on the behavior of the individuals involved. This pattern is similar to what happens to families. Fathurrohman (2017) says that the religiosity of friendship has a positive effect on understanding in attitude. Similar results also found by Pricilia (2013). From the above explanation can be drawn from the fifth hypothesis, that is:

$\mathrm{H}_{4}$ : The factors of friendship and the religiosity have a positive effect on the understanding of Riba.

Apart from family and friends, a person is usually also a part of a community or organization. Schein (2006) says that organizational culture inherent in an institution, both formal and informal will affect the formation of understanding, attitudes, and individual behavior. He further explains that every organization member will behave with the prevailing culture to be accepted by its environment. Saud (2016) found that organizational culture was able to encourage individual behavioral intentions to report fraud. These results are in line with those found by Sulistyo (2011) and Kusnaningsih (2014). From the description can be concluded that the culture in the organization will form the individual attitude, although sometimes occur unconsciously. From this argument can be formulated the last hypothesis that is:

$\mathrm{H}_{5}$ : Organizational Religiosity factors have a positive effect on the behavior in understanding riba.

\section{Research Method}

\section{Data and Sample}

The type of data used in this study was primary data in the form of respondent perceptions related research variables proposed, obtained by distributing questionnaires directly to them. Respondents in this study were 
accounting students at Muhammadiyah University of Yogyakarta (UMY). UMY Accounting students were chosen as the respondents' background of this campus graduates' motto of "Unggul dan Islami" (Excellent and Islamic) and focus on the development of sharia accounting as the concentration of accounting education held.

Respondent sampling technique used in this research was convenience sampling, that was a technique of selecting a sample from population element which its data easily collected, and researcher had right in choosing it to be used (Ulum \& Juanda, 2016). Data collection technique used in this study was a questionnaire as a means of collecting data in the real environment (Sekaran \& Bougie, 2010). The questionnaires were distributed directly with the aim of making the high-level response.

\section{Operational Definition of Variable}

The dependent variable is the variable influenced by the independent variable. The dependent variable in this research was student understanding about riba; something matters which encouraged a student could give information about the concept of riba, transactions that could arise riba, and danger when utilizing riba. The student's understanding of riba was measured based on the question distributed by using the Aprianti questionnaire (2017). The independent variables in this research were Intrinsic, Extrinsic, Learning, Family, Friends, and Organization. These variables were measured using questions adapted from the Mubarak questionnaire (2016):

1) Intrinsic education is an element in education commencing with an increase in self-learning of the individuals concerned.

2) Extrinsic education is anything that affects the learning activity that comes from outside and is not absolute.

3) Learning is a process of interaction between learners with educators and learning resources in a learning environment.

4) Family Religion is a common bond that has a function as a religious value.

5) Friendship Religiosity is a relationship between fellow human beings to show the activity of worship to God.

6) Organizational Religiosity is a system in which there is a sacred act of trust.

\section{Data Analysis}

Data analysis in this research included data quality test, the classical assumption test, and hypothesis test. The data quality test used a validity and reliability tests. The validity test applied statistical tools that were KMO and Bartlett's Test; an instrument would be valid if in testing KMO and Bartlett's Test showed the value above 0.05 (Nazaruddin \& Basuki, 2017). Reliability testing used Cronbach's Alpha method. A questionnaire was reliable if the results of the test yield a figure of $\geq 0.60$ (Sugiyono, 2012; 2014).

To find out a data that did not have a multicollinearity value was by looking at the cut off value that showed the tolerance value $>0.10$ or equal to VIF 
Table 1 Results of Questionnaire Distribution

\begin{tabular}{|c|l|c|c|}
\hline No & \multicolumn{1}{|c|}{ Information } & Total of Questionnaires & Percentage (\%) \\
\hline 1 & Number of questionnaires distributed & 109 & 100 \\
\hline 3 & Number of returned questionnaires & 109 & 100 \\
\hline 4 & Number of questionnaires that cannot be processed & 9 & 8,3 \\
\hline
\end{tabular}

$<10$. For heteroskedasticity test was measured using glejser test (Ghozali, 2018). Determination of independent variables presented to heteroscedasticity had a specific criterion that if the value of independent variable significance resulting in the glejser test showed greater value than alpha or 0.05; then it could be concluded that the regression model was free from heteroscedasticity normality using Kolmogorov-Smirnov Test. It was assumed that the residual data usually distributed if the significance value in the K-S table greater than alpha or 0.05. The hypothesis test used multiple regression test technique. The hypothesis would be accepted while the Sig value of the test result was less than alpha 0.05 and the regression coefficient was in the same direction as the formulated hypothesis.

\section{Result and Discussion}

\section{Overview and Research Subjects}

Respondents in the study were 100 students accounting students from the Muhammadiyah University of Yogyakarta. The distribution of questionnaires began on November 13, 2017, until November 24, 2017. Table 1 presents detailed results of the questionnaire distribution. In Table 2 the respondent profile is presented. Male respondents are dominant. Respondents spread over the ages of 20 to 22 years old. The majority of respondents are the students of the Academic year 2014. Respondents are balanced between the participating students in the organization and not participating in the organization.

Table 2 Characteristics of Respondents

\begin{tabular}{|c|c|c|c|}
\hline Criteria & Information & Total & Percentage (\%) \\
\hline \multirow[t]{3}{*}{ Sex } & Male & 66 & 66 \\
\hline & Female & 34 & 34 \\
\hline & Total & 100 & 100 \\
\hline \multirow[t]{7}{*}{ Age (years old) } & 18 & 1 & 1 \\
\hline & 19 & 14 & 14 \\
\hline & 20 & 32 & 32 \\
\hline & 21 & 20 & 20 \\
\hline & 22 & 32 & 32 \\
\hline & 23 & 1 & 1 \\
\hline & Total & 100 & 100 \\
\hline \multirow[t]{4}{*}{ Academic year } & 2014 & 61 & 61 \\
\hline & 2015 & 20 & 20 \\
\hline & 2016 & 19 & 19 \\
\hline & Total & 100 & 100 \\
\hline \multirow{3}{*}{$\begin{array}{l}\text { The participation in the } \\
\text { Organization }\end{array}$} & Participating & 50 & 50 \\
\hline & Not participating & 50 & 50 \\
\hline & Total & 100 & 100 \\
\hline
\end{tabular}


Table 3 KMO Validity Test and Bartlett's Test Results Kaiser-Meyer-Olkin Measure of Sampling Adequacy.

Bartlett's Test of Sphericity

\begin{tabular}{|l|r|}
\hline Approx. Chi-Square & 121,424 \\
\hline Df & 190 \\
\hline Sig. & 0.000 \\
\hline
\end{tabular}

\section{Data Quality Test}

From the Validity Test results show that the significant value of all questions is below 0.05 and the KMO value is 0.784 (See Table 3). It means that all the questions on the variables of education factor and the factor of religiosity level on the students' understanding about Riba and the data mean valid. The results of the reliability test show that all variables have met the criteria as the variable of reliability because it has a Cronbach alpha value over 0.60 (See Table 4).

\section{Hypothesis Test Results}

Table 5 describes Hypothesis test results. The results of the first hypothesis test indicate that intrinsic education variable affects the understanding of riba. The results of this study are relevant to research conducted by Ulinnuha (2015) who found that intrinsic education or more referred to the intention, knowledge, and motivation influence ethical behavior. The reason that makes intrinsic education influence significantly on the behavior in understanding riba is that intrinsic education becomes the principal basis in the individual to know what is right and wrong. At this time, the principle of confidence of individuals' identity is from experience and their education. Therefore, the religion of Islam is very focused on every individual to know his/her knowledge before charity. Do charity without the knowledge means doing more damage to the earth.

The results of the second hypothesis test confirm the educational extrinsic variable influence the understanding of riba. It is also related to the research conducted by Ulinnuha (2015) who found that extrinsic education or dreams caused ethical behavior. The results of this study also aligned with research conducted by Turere (2013) and Ningrum (2013) who found that extrinsic education or more called as the purpose and benefits of learning affect the formation of individual behavioral characters.

Table 4 Reliability Test

\begin{tabular}{|l|c|}
\hline Variables & Cronbach alpha Value \\
\hline Understanding of Riba & 0,721 \\
\hline Intrinsic education & 0,845 \\
\hline Extrinsic education & 0,850 \\
\hline Learning & 0,719 \\
\hline Family & 0,751 \\
\hline Friendship & 0,820 \\
\hline Organizational & 0,854 \\
\hline
\end{tabular}


Table 5 Hypothesis Test Results

\begin{tabular}{|c|l|c|c|c|}
\hline Code & Variable & Coefficients & Sig. & Conclusion \\
\hline $\mathrm{H}_{1 \mathrm{a}}$ & Intrinsic education &, 346 &, 013 & Accepted \\
\hline $\mathrm{H}_{1 \mathrm{~b}}$ & Extrinsic education &, 564 &, 020 & Accepted \\
\hline $\mathrm{H}_{2}$ & Learning &, 366 &, 038 & Accepted \\
\hline $\mathrm{H}_{3}$ & Family Religiosity &, 518 &, 027 & Accepted \\
\hline $\mathrm{H}_{4}$ & Friendship Religiosity &, 443 &, 044 & Accepted \\
\hline $\mathrm{H}_{5}$ & Organizational Religiosity &, 328 &, 014 & Accepted \\
\hline
\end{tabular}

Dependent Variable: Understanding of Riba

The reason that makes Extrinsic education has a positive effect on the behavior of Riba is that the interest of students who after their graduation want a career in sharia financial institutions is high, proved by non-economic graduates that are working in sharia financial institutions. Although for now, the policy has started to be specified only for graduates of economics.

The third hypothesis test shows that the educational learning variable influences the implementation of Riba. The results of this study correspond to the research conducted by Putri (2013) and Puspitawati (2010) who found that the learning education such as media education, education officers, and subjects affected the understanding of riba. The reason that makes educational learning has a positive effect on Riba behavior is there are lecturers at the Muhammadiyah University of Yogyakarta who specifically discuss the sharia, namely Sharia bank accounting courses, sharia accounting, sharia financial management and Islamic financial institutions of Indonesia.

The result of the study on the fourth hypothesis test shows that family religiosity variable influences the behavior in understanding riba. The results of this study are matching to the research conducted by Ulinnuha (2015) who found that family religiosity or known as the role of family influenced on ethical behavior. The results of this study are also relevant to the research conducted by Soemanto (2014) who found that the religiosity of the family or more referred to the family activities and information affected the child's ethical behavior.

The reason that makes family religiosity have a positive effect in the behavior of understanding riba is that family becomes the first environment for children to imitate everything done by the parents in front of them; in this stage, children do not yet know the good and bad things. When parents do bad things such as drinking alcohol, gamble, swearing, and stealing, then the children can imitate what their parents have done. On the other hand, in case the family (parents) always teach the value of Islamic education such as praying, reciting and speaking politely then the children will also tend to imitate the acts of both parents. It is like a proverb which says the fruit will not fall far from the tree. That is why the religiosity of the family becomes very important. Furthermore, the results of the fifth hypothesis test show that the variables of friendship religiosity affect the behavior of riba.

The results of this study conform to the research conducted by Fathurrohman (2017) who found that the friendship religiosity affected the behavior level. This result is relevant to the axioms. The Prophet Muhammad 
Sallallahu 'Alayhi Wa Sallam said that someone depends on the religion of his friend. Therefore, choose a good friend carefully is needed. In friendship, if someone habitual to gathering and hanging out with someone who likes to do Riba, then he/she will be affected and perform the same actions.

The result of the study on the sixth hypothesis test shows that the variable of organizational religiosity influence to Riba behavior. The results of this study are consistent with the research conducted by Saifullah (2016) who found that the religiosity of the organization or so-called the organizational environment affected the understanding, attitude, and behavior. The organizational religiosity has a significant effect on behavior in understanding riba because the organizational culture is the norms and values that direct the behavior of the members of the organization. After that, each member of the organization will behave related to the prevailing culture that accepted by his/her environment.

\section{Conclusion}

Based on the results of the analysis, the conclusion is all independent variables (Intrinsic education, extrinsic education, educational learning, family religiosity, friendship religiosity, and organizational religiosity) influence on the dependent variable represented by behavior in understanding riba. Designing a curriculum that can produce the determinant is necessary to improve the understanding of accounting students about Riba, namely: Intrinsic education, extrinsic education, educational learning, family religiosity, and organizational religiosity.

This study has several limitations. Firstly, this study only utilized the questionnaire which made the results depend on its quality. If there are different perceptions among students who in this study made as a respondent will affect to the bias notion and filling out the questionnaire will not be perfect. This study took 100 respondents from the Muhammadiyah University of Yogyakarta. This study did not conduct any different test on students who participate the organizations with students who did not participate in an organization. In the research instrument section for student understanding variable about Riba, it still cannot measure accurately, so the instrument is still weak to be the basis for further research.

From some of these limitations, the suggestion for future research is, firstly, further research is expected to develop a more specific questionnaire and more directed to the example of the behavior in understanding Riba. Secondly, further research is expected to increase the sample and expand the number of universities where its students are available as respondents. There are some universities with sharia accounting courses, but it was not included as the research objects. Finally, further researches are expected to do a test on different students who participate in the organization compared to those who do not participate in the organization. 


\section{References}

Al-Qur'an.

Al-Hadits.

Ryan, R. M., \& Deci, E. L. (2000). Intrinsic and extrinsic motivations: Classic definitions and new directions. Contemporary educational psychology, 25(1), 54-67. doi: 10.1006/ceps.1999.1020

Ajzen, I. (1991). The theory of planned behavior. Organizational behavior and buman decision processes, 50(2), 179-211. doi: 10.1016/0749-5978(91)90020$\mathrm{t}$

Ajzen, I., \& Fishbein, M. (2005). 5. The influence of attitudes on behavior. In The bandbook of attitudes,173-222.

Antonio, M. S. I. (2001). Bank syariah: Dari teori ke praktik. Jakarta: Gema Insani. Apriyanti, H. W. (2017). Akuntansi syariah: sebuah tinjauan antara teori dan praktik. Jurnal Akuntansi Indonesia, 6(2), 131-140. doi: 10.30659/jai.6.2.131-140

Cohen, J. R. and N. M. Bennie. 2006. The applicability of a contingent factors model to accounting ethics research, Journal of Business Ethics, 68(1), 1-18. doi: 10.1007/s10551-006-9036-2

Fathurrohman, M. (2016). Pembawaan, keturunan, dan lingkungan dalam perspektif islam. KABILAH: Journal of Social Community, 1(2), 379-406.

Fishbein, M., \& Ajzen, I. (1974). Attitudes towards objects as predictors of single and multiple behavioral criteria. Psychological review, 81(1), 59-74. doi: $10.1037 / \mathrm{h} 0035872$

Fishbein, M., dan Ajzen, I. (1975). Belief, attitude, intention, and behavior: An introduction to theory and research. Reading: Addison-Wesley.

Ghozali, I. (2018). Aplikasi analisis multivariete dengan program IBM SPSS 23. Badan Penerbit Universitas Diponegoro.

Jones, T. M. (1991). Ethical decision making by individuals in organizations: An issue-contingent model. Academy of management review, 16(2), 366-395. doi: 10.5465/amr.1991.4278958

Kusnaningsih, W. (2014). Pengaruh budaya religius sekolah (dipilin hafalan surat yasin dan sholat berjma'ah). Master Thesis, IAIN Tulungagung.

Juanda, \& Sofyani, H. (2016). Konsep pendidikan karakter keagamaan untuk calon akuntan studi kasus di program studi akuntansi universitas muhammadiyah yogyakarta. Jurnal Akuntansi dan Investasi, 17(2), 186-196. doi: 10.18196/jai.2016.0054.186-196

Majelis Ulama Indonesia. (2004). Keputusan Fatwa Majelis Ulama Indonesia Nomor 1 tabun tentang bunga bank.

Ma'rifah, D., \& Indrayanto, A. (2013). Pengembangan etika kerja berbasis islam: kajian tentang kepuasan kerja, komitmen organisasional, dan perilaku kewargaan organisasional. Sustainable Competitive Advantage (SCA), 3(1), 55-67.

Mazereeuw-van der Duijn Schouten, C., Graafland, J., \& Kaptein, M. (2014). Religiosity, CSR attitudes, and CSR behavior: An empirical study of executives' religiosity and CSR. Journal of business etbics, 123(3), 437-459. doi: 10.1007/s10551-013-1847-3

Mubarak, Z. (2016). The influence of religiosity on ethical decision making: review of indonesian accounting students. Doctoral Dissertation, Victoria University.

Mayhew, B. W., \& Murphy, P. R. (2008). The impact of ethics education on reporting behavior. Journal of Business Ethics, 86(3), 397-416. doi: 10.1007/s10551-008-9854-5

Nazaruddin, I., \& Basuki, A. T. (2015). Analisis statistik dengan SPSS. Yogyakarta: Danisa Media.

Ningrum, W., B. S. Sunuharyo, dan M. S. Hakam. (2013). Pengaruh pendidikan dan pelatihan terhadap kinerja karyawan. Jurnal Administrasi Bisnis, 6(2), $1-8$. 
Pawitasari, E., Mujahidin, E., \& Fattah, N. (2015). Pendidikan karakter bangsa dalam perspektif Islam (studi kritis terhadap konsep pendidikan karakter kementerian pendidikan \& kebudayaan). TA'DIBUNA, 4(1), 1-20.

Prasetya, Y. S. (2015). Riba dan ketidakadilan sistem ekonomi kapitalisme: Sebuah kajian teoritis. EKSYAR: Jurnal Ekonomi Syari'ah \& Bisnis Islam, 2(2), 472-493.

Pricila, A., Ulfah, M., \& Basri, M. (2013). Pengaruh pergaulan teman sebaya terhadap rasionalitas ekonomi mahasiswa pendidikan ekonomi FKIP Untan. Jurnal Pendidikan dan Pembelajaran, 2(3), 151-163.

Puspitawati, H. (2010). Pengaruh karakteristik sosial ekonomi keluarga terhadap pola asuh belajar siswa sekolah dasar dan menengah pertama. Jurnal Ilmu Keluarga \& Konsumen, 3(1), 46-55. doi: 10.24156/jikk.2010.3.1.46

Putri, C. (2013). Pengaruh kreativitas belajar, penggunaan media pembelajaran power point, dan lingkungan keluarga terhadap hasil belajar mata pelajaran akuntansi pada siswa kelas $\mathrm{x}$ akt smk negeri 2 blora tahun ajaran 2012/2013 (motivasi belajar sebagai variabel interve. Economic Education Analysis Journal, 2(2), 231-245.

Rahman, U. (2009). Perilaku religiusitas dalam kaitannya dengan kecerdasan emosi remaja. Jurnal Al-Qalam, 15(2)114-122.

Rahma, N., Yulianti, R. T., \& Sofyani, H. (2018). Perilaku etis individu dalam pelaporan keuangan: Peran pendidikan berbasis syariah dan komitmen religiusitas. Jurnal Akuntansi dan Kenangan Islam, 6(1), 57-83.

Rahmanti, V. N. (2015). Sebuah kajian mengapa akuntansi syariah masih sulit tumbuh subur di indonesia. Jurnal Akuntansi dan Investasi, 13(2), 161-179.

Rahmanti, V. N. (2017). Mengungkap kesadaran islami atas riba pada proses pembelajaran akuntansi. Jurnal Akuntansi dan Investasi, 18(2), 141-152. doi: 10.18196/jai.180278

Saifullah, I. (2016). Sikap toleransi dalam menghadapi perbedaan ideologi keagamaan pada aktivis imm di kota yogyakarta. Master Thesis, Universitas Muhammadiyah Yogyakarta.

Saud, I. M. (2016). Pengaruh sikap dan persepsi kontrol perilaku terhadap niat whistleblowing internal-eksternal dengan persepsi dukungan organisasi sebagai variabel pemoderasi. Jurnal Akuntansi dan Investasi, 17(2), 209-219. doi: 10.18196/jai.2016.0056.209-219

Schein, E. H. (2006). Organizational culture and leadership (Vol. 356). New Jersey: John Wiley \& Sons.

Sekaran, U., \& Bougie, R. (2010). Research method far business: a skill building approach. Chichester: John Wiley \& Sons Ltd

Soemanto, R. (2014). Sosiologi keluarga. http:// repository.ut.ac.id/4652/2/SOSI4413-TM.pdf

Sofyani, H., \& Pramita, Y. D. (2013). Otoritas atasan, retaliasi dan locus of control sebagai faktor-faktor yang memengaruhi perilaku manipulasi laporan realisasi anggaran. Jurnal Reviu Akuntansi dan Keuangan, 3(2), 427436.

Sofyani, H., Anggraini, M. R. F., \& Ayunani, S. (2016). Islamic education mentoring program and the religiousity of prospective accountant. Shirkab: Journal of Economics and Business, 1(2), 185-206. doi: 10.22515/shirkah.v1i2.33

Sugiyono. (2012). Statistika untuk penelitian. Bandung: Alfabeta.

Sugiyono. (2014). Metode penelitian bisnis: pendekatan kuantitatif, kualitatif, dan R\&D. Bandung: Alfabeta.

Sulistyo, H. (2011). Peran nilai-nilai religiusitas terhadap kinerja karyawan dalam organisasi. Media Riset \& Manajemen, 11(3), 252-270.

Turere, V. N. (2013). Pengaruh pendidikan dan pelatihan terhadap peningkatan kinerja karyawan pada balai pelatihan teknis pertanian kalasey. Jurnal Riset Ekonomi, Manajemen, Bisnis dan Akuntansi, 1(3), 10-19. 
Ulinnuha, A. (2015). Implementasi pola pengasuban anak pada santri usia 7-12 tabun dalam pembentukan karakter di pondok pesantren al-muqaddasah ponorogo jawa timur. Master Thesis, Universitas Islam Sunan Kalijaga.

Ulum, I., \& Juanda, A. (2016). Metodelogi penelitian akuntansi: klinik skripsi edisi 2. Yogyakarta: Aditya Media Publishing.

Ulum, K. (2016). Hakikat keharaman riba dalam islam. JES Jurnal Ekonomi Syariab), 1(1), 115-126. doi: 10.30736/jes.v1i1.8

Widyarini, W., \& Sugiarto. (2017). Pengaruh kebebasan dalam bekerja, lingkungan keluarga, dan keberanian mengambil resiko terhadap minat berwirausaha. Jurnal Az Zarqa, 6(2), 171-182.

Yaya, R. (2016). Socio religious settings and the development of accounting in indonesia. Jurnal Akuntansi dan Investasi, 6(1), 56-73. 